Viktoria Ferencsik, Gyula Varga,

Miskolc, Hungary

\title{
EXAMINATION OF THE CHANGE IN SURFACE ROUGHNESS OF BURNISHED LOW ALLOYED ALUMINIUM EXTERNAL CYLINDRICAL PIECES
}

\begin{abstract}
The life and reliability of machine components or elements are affected greatly by the surface integrity. Machined surfaces by conventional processes such as turning and milling have inherent irregularities and defects like tool marks and scratches that cause energy dissipation (friction) and surface damage (wear). Ball burnishing has proved to be a highly effective mechanical finishing process of industrial workpieces because of the excellent surface roughness and fatigue performance that induces in treated components. This paper focuses on the examination of the influence of different burnishing parameters, such as number of passes (i), feed rate $(f)$ and burnishing force $(F)$. For plan and execute the experiments we use full factorial experimental design method by which empirical formulas can be created easily. The measurement of the surface roughness was executed with Altisurf 5203 D measuring equipment at the Institute of Manufacturing Science. The measured results were evaluated by the comparison of a special correlation formula to determine the optimal combination level of the different parameters in the given interval.
\end{abstract}

Keywords: surface roughness; polishing options; 3D roughness of the surface; polishing power.

\section{INTRODUCTION}

Surface integrity of manufactured components plays vital role to avoid friction losses, good corrosion resistant property and high fatigue life. Mechanical machining of different parts it is possible to improve life time by selecting the right process and/or the adequate technological data [1], [2]. Surface roughness can be reduced by turning [3] or milling [4], [5] more efficiently but conventional machining processes cannot modify the properties of the subsurface layer. On the other hand, ball burnishing is a mechanical finishing treatment, performed on workpieces to enhance their mechanical properties and improving their performance to highly demanding working conditions [6-8]. Nevertheless, burnishing has a special characteristic that differentiates it from the other mentioned processes, that is, residual compressive stresses are induced in the workpiece surface through one or more passes of the burnishing tool, thus enhancing the fatigue performance of the piece and inhibiting the origin of cracks and notches on parts [7], [9]. 
This work presents a comparing analysis of surface roughness focusing on the determination of each process parameter (I, f, F) influence and the interest of it full factorial experimental design method was used in our investigation [10], [11] which is valid in between the minimum and maximum values of the above mentioned parameters.

\section{BURNISHING OF OUTER CYLINDRICAL SURFACES}

Surface burnishing is a force controlled forming process, which is widely applied on finishing rotationally symmetrical parts e.g. found in the automotive and aeronautics industries.

A burnishing tool is pressed under a force onto the workpiece surface and this pressure is generated by the ball exceeds the yield point of the softer piece part surface at the contact area, resulting plastic deformation on the surface structure [6], [12]. As seen in Fig. 1 a tangential sliding displacement of the tool deforms the material of the component, which results the reduction of the roughness, while an increase in compressive residual stress at the boundary layer is achieved [12].

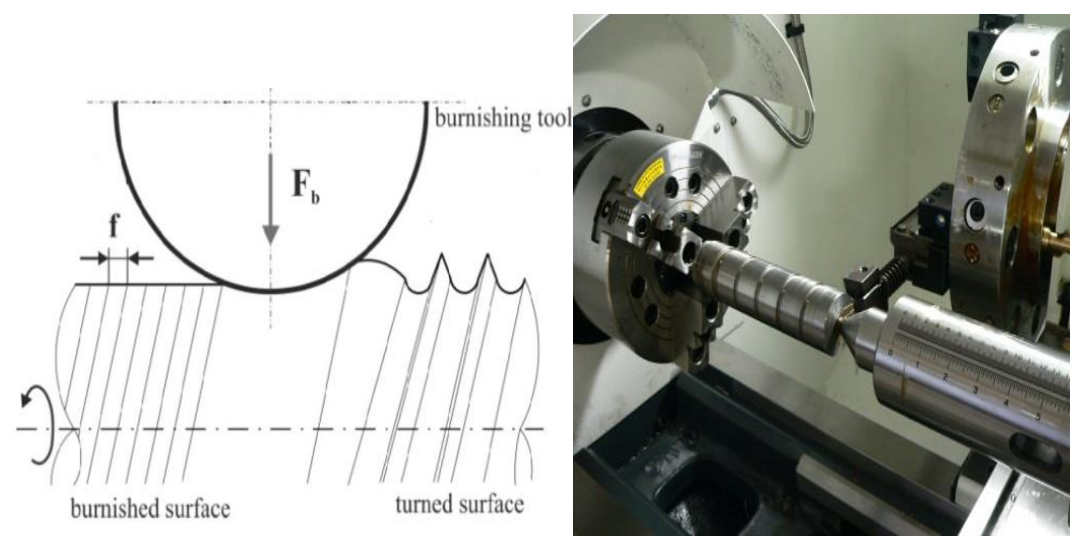

Figure 1 - Schematic illustration of burnishing process [12] and the technological solution of it

Burnishing of outer cylindrical surfaces can be executed on conventional universal lath or up-to-date $\mathrm{CNC}$ lath, the latter one was applied as Fig. 1 shows. 


\section{IMPLEMENTATION OF THE EXPERIMENT}

\subsection{Material and parameters}

For this experiment we have chosen lightly alloyed aluminium material as automobile, aeronautics and astronautics industries more and more claims for the application of non-ferrous materials due to its low density and good mechanical properties [13].

The operation was performed with a spherical $(\mathrm{R}=3.5 \mathrm{~mm})$ polycrystalline diamond tool attached to OPTIMUM type OPTIturn S600 CNC machine with different set-ups depending on the full factorial experimental design method.

The following burnishing parameters were examined: number of tool passes, feed rate and burnishing force, as it can be seen on Table 1 all of it have a lower and a higher values according to the matrix experimental design, containing the burnishing parameters in natural dimensions and their transformed values.

Table 1 - The burnishing parameters

\begin{tabular}{|c|c|c|c|c|c|c|}
\hline \multirow{2}{*}{ No. } & \multicolumn{3}{|c|}{ Adjusted parameters } & \multicolumn{3}{c|}{ Transformed parameters } \\
\cline { 2 - 7 } & $\mathrm{i}[\varnothing]$ & $\mathrm{f}[\mathrm{mm} / \mathrm{rev}]$ & $\mathrm{F}[\mathrm{N}]$ & $\mathrm{X}_{1}$ & $\mathrm{X}_{2}$ & $\mathrm{X}_{3}$ \\
\hline 1 & 1 & 0.001 & 10 & -1 & -1 & -1 \\
\hline 2 & 3 & 0.001 & 10 & +1 & -1 & -1 \\
\hline 3 & 1 & 0.005 & 10 & -1 & +1 & -1 \\
\hline 4 & 3 & 0.005 & 10 & +1 & +1 & -1 \\
\hline 5 & 1 & 0.001 & 20 & -1 & -1 & +1 \\
\hline 6 & 3 & 0.001 & 20 & +1 & -1 & +1 \\
\hline 7 & 1 & 0.005 & 20 & -1 & +1 & +1 \\
\hline 8 & 3 & 0.005 & 20 & +1 & +1 & +1 \\
\hline
\end{tabular}

\subsection{Measuring of surface roughness}

The measurement of the 3D surface roughness of the specimens before and after burnishing was carried out on AltiSurf 520 type 3D surface roughness tester with chromatic confocal sensor at the Institute of Manufacturing Science. we used the own software of the roughness measuring device (PhoeNix) to evaluate the measurement values. The individual sections were measured three times, rotated at $120^{\circ}$ fixed in prism.

Figure 2 illustrates a state of measurement process. 


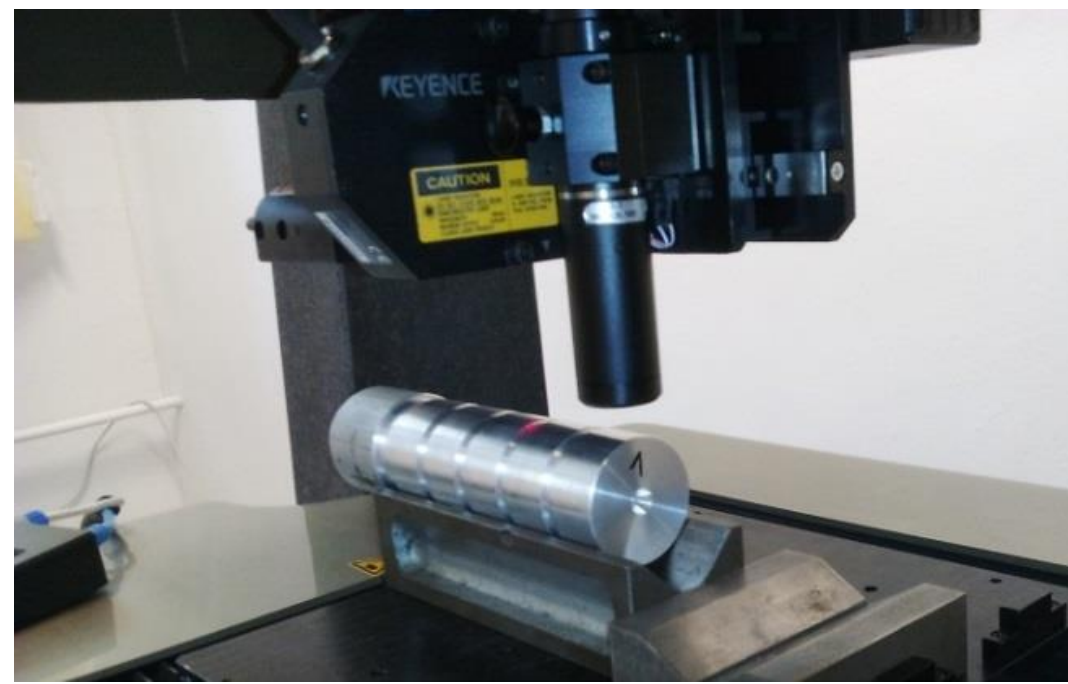

Figure 2 - Measurement process of 2D surface roughness

\section{RESULTS}

In our investigation we have created a dimensionless ratio to make the changing of surface average roughness more obvious, which are shown in formula (1) and (2):

where:

$$
\begin{aligned}
& \rho_{\text {Ra }}=\frac{\text { Ra } a_{\text {burnished }}}{R a_{\text {turned }}} \\
& \rho \%=\left(\rho_{\text {Ra }}-1\right) \cdot 100,
\end{aligned}
$$

$\rho_{\mathrm{Ra}} \quad$ Degradation ratio of surface roughness $(\mathrm{Ra})$ parameter. This is a dimensionless ratio, which textures the changes occurring because of burnishing,

$\mathrm{Ra}_{\text {burnished }}$ Surface roughness remain after burnishing,

$\mathrm{Ra}_{\text {turned }} \quad$ Surface roughness remain after turning, $\rho \% \quad$ The percentage value of the improvement ratio.

The lowest the value of $\rho_{\mathrm{Ra}}$ in the negative range, the greater is the improvement.

The measured data and the calculated improvement ratios are summarized in Table 3. 
Table 2 - Measured values and calculated improvement ratios

\begin{tabular}{|c|c|c|c|}
\hline \multirow{2}{*}{ No. } & \multicolumn{2}{|c|}{$\overline{R a}[\mu \mathrm{m}]$} & \multirow{2}{*}{$\rho_{\mathrm{Ra}}[\%]$} \\
\cline { 2 - 3 } & Turned & Burnished & \\
\hline 1 & 1.1226 & 0.3457 & $\mathbf{- 6 9 . 2 1}$ \\
\hline 2 & 1.0118 & 1.8215 & $\mathbf{8 0 . 0 3}$ \\
\hline 3 & 0.9947 & 0.3599 & $\mathbf{- 6 3 . 8 2}$ \\
\hline 4 & 0.9450 & 0.2516 & $\mathbf{- 7 3 . 3 8}$ \\
\hline 5 & 0.9213 & 1.2686 & $\mathbf{3 7 . 6 5}$ \\
\hline 6 & 1.0622 & 2.2249 & $\mathbf{1 0 9 . 4 6}$ \\
\hline 7 & 1.0679 & 0.5875 & $\mathbf{- 4 4 . 9 9}$ \\
\hline 8 & 1.0741 & 1.3817 & $\mathbf{2 8 . 6 4}$ \\
\hline
\end{tabular}

Application of Factorial Experiment Design method empirical formula (3) was created from the calculated values. Calculations and axonometric figure (Fig. 3) was prepared using „MathCAD 15.0” software.

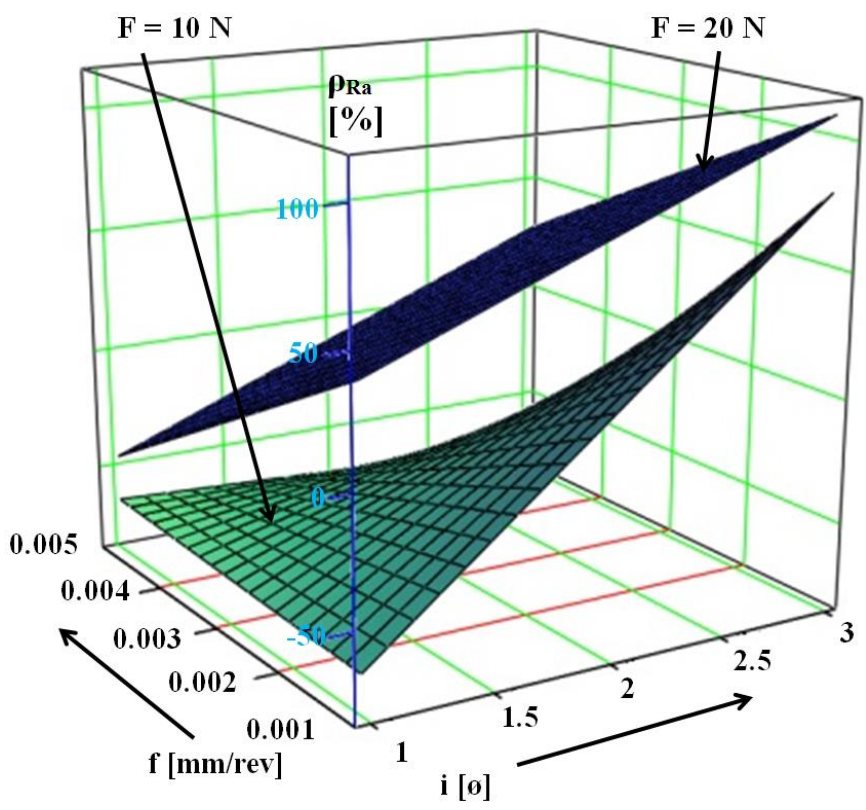

Figure 3 - Changing of surface roughness 


$$
\begin{gathered}
\rho_{R a}=-352.6875+153.263 \times i+6.328 \times 10^{4} \cdot f+18.766 \cdot F- \\
-3.993 \times 10^{4} \times i \times f-5.879 \times i \cdot F-4.208 \times 10^{3} \times f \times F+2.008 \times i \cdot f \cdot F(3)
\end{gathered}
$$

\section{SUMMARY AND DISCUSSIONS}

The paper deals with the experimental analysis of sliding burnishing when the material of the workpiece was low-alloyed aluminium. Experimental parameters were the number of passes, feed rate and burnishing force. The aim of the experiments was how these parameters have effect to the surface roughness.

On the base of the present research work it can be stated:

Among the examined parameters the effect of burnishing force is the most dominant and it is seems to be there is a linear interaction with the number of passes; according to it we would like realize further examination with the application of lower burnishing force $(F)$

The higher improvement was caused by the application of these burnishing parameters:

$$
\begin{gathered}
\mathrm{i}=3 \\
\mathrm{f}=0.005 \mathrm{~mm} / \mathrm{rev} \\
\mathrm{F}=10 \mathrm{~N}
\end{gathered}
$$

\section{ACKNOWLEDGEMENTS}

"The described study was carried out as part of the EFOP-3.6.1-16-00011 "Younger and Renewing University - Innovative Knowledge City institutional development of the University of Miskolc aiming at intelligent specialisation" project implemented in the framework of the Szechenyi 2020 program. The realization of this project is supported by the European Union, co-financed by the European Social Fund."

"Project no. NKFI-125117 has been implemented with the support provided from the National Research, Development and Innovation Fund of Hungary, financed under the K_17 funding scheme."

References: 1. J. Kundrak: Alternative machining procedures of hardened steels, Manufacturing Technology, 11, (2011) 32-39. 2. M. Horvath, J. Kundrak, A. G. Mamalis, K. Gyani: On the precision grinding of advanced ceramics, International Journal of Advanced Manufacturing Technology, 20 (4), (2002) 255-258. 3. J. Kundrak, K. Gyani, V. Bana: 3D roughness parameters of surface face milled by special tools, International Journal of Advanced Manufacturing Technology, 38 (1-2), (2008) 110-119. 4. J. Kundrak, C. Felho: 3D parameters of surface face milled by special tools, Manufacturing Technology, 16 (3), (2016) 532-538 5. C. Felho, J. Kundrak: Comparison of theoretical and real surface roughness in face milling with octagonal and circular inserts, Key Engineering Materials, 581, (2014) 360-365. 6. A. P. Borkar, P. S. Kamble, C. Y. Seemikeri: Surface Integrity Enhancement of Inconel 718 by using Roller Burnishing process, Int. J. of Current Engineering and Technology, 4 (4), (2014) 2595-2598. 7. G. Gomez-Gras, J. A. 
Travieso-Rodriguez, R. Jerez-Mesa: Experimental characterization of the influence of lateral pass width on results of a ball burnishing operation, Procedia Engineering, 132, (2015) 686-692. 8. A. M. Hassan: The effects of ball- and roller-burnishing on the surface roughness and hardness of some non-ferrous materials, Materials Processing Technology, 72, (1997) 385-391. 9. N. H. Loh: Effects of ball burnishing parameters on surface finish, Journal of Precision Engineering, 10, (1998), 215 220. 10. L. Fridrik: Chosen chapters from the topics of experimental design of production engineering, Műszaki Könyvkiadó, Budapest, 1987 (In Hungarian). 11. L. Bálint, L. Gribovszki (1975). The basics of machine engineering technology, Miskolc, pp: 418-442. (in Hungarian). 12. M. Posdzich, R. Stöckmann, F. Morczinek, M. Putz: Investigation of a plain ball burnishing process on differently machined Aluminium EN 2007 surfaces, MATEC Web of Conferences, 190, 11005, (2018) p. 7.

\title{
Вікторія Ференчик, Дюла Варга, Мішкольц, Угорщина
}

\section{ДОСЛІДЖЕННЯ ЗМІНИ ШОРСТКОСТІ ПОВЕРХНІ ЦИЛІНДРИЧНИХ ДЕТАЛЕЙ 3 НИЗЬКОЛЕГОВАНОГО АЛЮМІНІЮ ПРИ ПОЛІРУВАННІ}

\begin{abstract}
Анотація. Термін служби і надійність компонентів або елементів машини в значній мірі залежить від иілісності їх поверхні. Оброблені звичайними процесами поверхні, такими як токарна обробка і фрезерування, мають властиві нерівності і дефекти, такі як сліди інструменту $i$ подряпини, які викликають розсіювання енергії (тертя) $i$ пошкодження поверхні (знос). Полірування підшипникових кульок зарекомендувало себе як високоефективний процес механічної обробки промислових деталей через чудову шорсткість поверхні $i$ втомних характеристик, щэо виникають в наслідок обробки компонентами. Ця стаття присвячена вивченню впливу різних параметрів полірування, таких як кількість проходів (i), швидкість подачі $(f)$ і сила полірування $(F)$. Для планування $i$ проведення експериментів було використовано метод факторного планування експерименту, за допомогою якого можна легко створювати емпіричні формули. Для иього експерименту вибрали легкосплавний алюмінієвий матеріал, який широко використовується в автомобільній, авіаційній та космічній галузях, де все більше $i$ більше претензій на застосування кольорових матеріалів через їх низької щільності $i$ хороших механічних властивостей. Операція виконувалася за допомогою сферичного полікристалічного алмазного інструменту, закріпленого в верстаті з ЧПУ з різними настройками в залежності від умов факторного експерименту. Вимірювання шорсткості поверхні було виконано за допомогою вимірювального обладнання Altisurf 520 3D в Інституті виробничих наук. Виміряні результати оцінювалися шляяом порівняння за спеціальною формулою корелячії для визначення оптимального рівня комбінації різних параметрів в даному інтервалі. На підставі даної дослідницької роботи можна констатувати, що серед розглянутих параметрів вплив поліруючої сили є найбільш домінуючим, $i$, схоже, існує лінійна взаємодія з числом проходів; відповідно до чого потрібно б провести подальшу перевірку із застосуванням більи низької сили полірування (F).
\end{abstract}

Ключові слова: шорсткість поверхні; параметри полірування; 3D шорсткість поверхні; сила полірування. 